\title{
The Asymmetric Distribution of Taxation Powers in the Spanish State of Autonomies: The Common System and the Foral Tax Regimes
}

\author{
VIOLETA RUIZ ALMENDRAL
}

The purpose of this article is to analyse the present arrangements for financing devolved government in Spain and, specifically, to explain why there is such great asymmetry between the topowers of the historic or foral autonomous communities (ACs) - the Basque Country and Navarra - and the so-called 'common system', which applies to the other ACs.

This article focuses on the assignment of taxation/powers, as this area has very recently been substantially reformed and is bound to become one of the main issues in future relations between thy central state (hereafter the 'State') and ACs. Although differes between the common and foral tax systems prevail, the 1997 and 2002 reforms of the common financing system have led to some convergenee. Greater convergence has been identified by some comprentators as a means of increasing the transparency and fiscal responsibility of the whole financing system, and making a distinction between the legitumate exercise of taxation powers and tax competition among ACs, which is prohibited by the Spanish Constitution (Ramallo, 1995: 13-14).y

\section{THE PROBLEM OF CLASSIFYING SPANISH DECENTRALIZATION}

The Spanish Constitution of 1978 deliberately omits any reference to the form of the State. That is, it does not describe it as centralized, federal or regional. After almost 40 years of Franco's highly centralized government, consensus on this matter was anything but easy to obtain. The closest precedent for decentralization in Spain was established by the Constitution of 1931 - the Second Spanish Republic - and lasted only eight years (1931-39). This model was intentionally not followed; its tragic ending in the Civil War did not make this advisable. For over a century before the Republic, Spain had been a centralized state, with unresolved regionalist demands (López Guerra, 1996: 145ff; Moreno, 1999: 150ff).

Violeta Ruiz Almendral, ???

Regional and Federal Studies, Vol.13, No.4, Winter 2004, pp.41-66

PUBLISHED BY FRANK CASS, LONDON 
The framers of the 1978 Constitution had before them one of the most difficult tasks that Spanish politicians could ever come across: to resolve the 'regional question' for good. This challenge was met by not defining the new system, but by establishing a procedural framework instead. Thus, what the Constitution does is to establish an 'optional autonomy system' (the so-called 'principio dispositivo') (De Otto y Pardo, 1995: 256). Certain groups of provinces, provided that they have common historical, cultural and economic characteristics, have the right to decide whether they want to become an AC (section 143 of the Constitution). If they decide to do so, they then have to choose which matters they want to be in charge of. In other words, this is autonomy 'à la carte' or a 'cheese platter' system (López Guerra, 1998: 258).

The Constitution does not actually assignexplicit authority to ACs, but affords them the possibility of taking authority oyer a group of matters listed in the Constitution (Sections 148 and 149). Itdoes, however, reserve special functions for the State. Thus, for example, the State is in charge of 'regulating the basic conditions to ensure the equality of all Spaniards in the exercise of their rights and the fulfilment of their obligations' (Section 149.1.1a), and is assigned exclusive authority for 'coordination of the economy' (Section 149.1.13a).

Despite the existence of $\mathrm{wg}$ kists of areas of authority in the Constitution - those for ACs to choose from, and those for the State to undertake - the division of authority does not end there, as Section 149.3 establishes a series of provisions that may change the actual distribution of authority. Thus, ACs may take on the authority not expressly assigned to the State by the Constitution and the State may take on the authority not taken on by ACs. In the case of a conflictover which tier should be assigned a given matter, the laws enacted by the State will prevail over the ACs. Lastly, Section 149.3 establishes that the laws of the State will at any rate be supplementary to those of the ACs (e.g. in the case of legal gaps or loopholes, or where an AC's regulation is incomplete or unclear). This last provision has been the object of much controversy, as the Constitutional Court in Opinions $118 / 1996$ and 61/1997 radically changed its interpretation to avoid the use of the provision as an indirect means for the State to retrieve authority from ACs (García de Enterría and Fernández, 1999: 345ff; Ruiz Almendral, 2002b).

The Constitution allows the State to control ACs in some cases (eg Sections 150.3, 153 and 155). In practice, these provisions have never been invoked. Instead, the numerous conflicts have been solved - or are in the process of being solved - through politically negotiated agreements.

One relevant feature of the constitutional design of the State is the strong role that the State is bound to play in the distribution of authority. This can 
be explained by the coexistence of the principle of autonomy and the principle of unity. They are both expressed in Section 2: 'The Constitution is grounded on the indissoluble unity of the Spanish Nation ... and guarantees and recognizes the right to autonomy of its regions.' This apparent oxymoron has been the subject of many decisions of the Constitutional Court (inter alia, in Opinions 4/1981; 25/1981; and 37/1981), which has repeatedly stated that it is within the unity of the State that autonomy can be realized (López Guerra, 1993 and 1996).

This process has given rise to a form of state that is not easily definable. The 'politically correct' term by which Spain is usually defined is that of 'State of Autonomies' (Estado de las autonomías). But if one considers the broad scope of decentralization in Spain and the authority gained by the ACs over the past 20 years, one has to conclyde that - and this has become quite a controversial issue - Spain is, in practice if not in legal form, a federal state. ${ }^{1}$

THE ASYMMETRIC MODEL AND THE NEED FOR BILATERAL AND MULTILATERAL AGREEMENTS

Probably the most striking feature of the Spanish devolution process is the speed at which it has developgd. Betwegn 1978 and 1983, all the Spanish regions engaged in this process, so that the whole country is presently divided into 17 Gs. The evolytion of public expenditure clearly shows the speed of the devolution process. Table 1 shows that, in 1978, the State was in charge of 89.0 per cent of public expenditure; only 23 later, this had dropped to 51.0 per cent, with ACs in charge of 32.5 per cent. Another important feature of this model of the State is its asymmetry. This asymmetry is both de facto and de jure (Watts, 1999: 28ff; Agranoff, 1999:

TABLE 1

THE DECENTRALIZATION OF PUBLIC EXPENDITURE (\% SHARE OF TOTAL PUBLIC EXPENDITURE)

\begin{tabular}{lccc}
\hline Year & State & Autonomous Communities & Municipalities \\
\hline 1978 & 89.0 & - & 11.0 \\
1984 & 72.6 & 14.4 & 13.0 \\
1987 & 66.7 & 18.7 & 14.6 \\
1990 & 59.6 & 23.9 & 16.5 \\
1992 & 57.0 & 26.6 & 16.4 \\
1998 & 51.0 & 32.5 & 16.5 \\
\hline
\end{tabular}

Source: Monasterio Escudero and Suárez Pandiello, 1998: 79. This table presumes that all ACs have the same set of functions from 1998, which is exactly the situation as of 1 January 2002. More detailed data are available at http://www.estadief.minhac.es/ (the official web site of the Ministry of Finance). 
TABLE 2

DIFFERENT QUANTITATIVE WEIGHT OF SLOW- AND FAST-LANE COMPETENCIES

\begin{tabular}{lc}
\hline Areas of authority & $\%$ of the total \\
\hline Slow-lane matters & 18.18 \\
Education & 38.61 \\
Health & 43.21 \\
\hline
\end{tabular}

Source: Monasterio Escudero and Suárez Pandiello, 1998: 59. This table reflects the average cost of this authority taking into consideration both what it used to cost the State before it was transferred and what it actually costs the ACs once it is transferred. Needless to say, the cost will greatly differ depending on the AC (e.g. some ACs, such as Extremadura, are known for having a significant percentage of retired population)

96ff; Moreno, 1999: 151ff) and explains the key role played by political agreements.

There are two principal reasons why the State of Autonomies is asymmetrical. The first lies in the procedural frangework established by the Constitution. It provides two special procedures for ACs to be formed. They differ in that one allows for fuller and faster autonomy, while the other entails a more limited and gradua attainment of autonomous powers. These are usually referred to as the 'fast-lane' and 'slow-lane' processes. Fast-lane ACs may initially take onvmore authority, including health and education, which together representabout 80 per cent of total policy competence that can be taken gn by ACs)(see Table 2). Eventually, slow-laners may increase their authority and goin access to the maximum level, provided that they follow the process established in Section 148.2. ${ }^{2}$

The original ided of the framers of the Constitution was that some ACs with past experience of self-government should be given the opportunity to become fast-laners from the beginning, while the rest would have to start by being slow-laners. Hence the second transitional provision of the Constitution, which establishes fast access to autonomy for those ACs which had approved self-government statutes in the past (i.e. during the Second Republic). These were to be Catalonia, the Basque Country and Galicia, which had not only had brief access to autonomy in the years of the Republic but also had more or less in common a strong nationalist sentiment fuelled by the existence of different languages. In the end, however, seven ACs became fast-laners: in addition to the aforementioned three: Andalusia, Navarra, Valencia and the Canary Islands adopted the higher level of autonomy. The other ten ACs remained with a lower level of autonomy until 2002, when they 'caught up' with the fast-laners.

The second explanation for asymmetry lies in the recognition of the historic rights of some regions, enshrined in the first additional provision of 
the Spanish Constitution. This has resulted in the Basque Country and Navarra having a much greater level of competences, especially in fiscal matters.

The first type of asymmetry can be categorized as de facto or transitorial; it refers only to the initial process, but does not prevent all ACs from eventually gaining access to the same level of authority. The second type is a de jure asymmetry, of a much more controversial nature.

This explains why bilateral and multilateral agreements have played a very important role in the assignment of authority. Bilateral agreements have been necessary to address the different autonomy aspirations of ACs. Moreover, in the case of the Basque Country and Navarra, bilateral agreements were the only possible way to address the special status that they, as 'historic communities', were granted by the 1978 Constitution. Multilateral agreements have coexisted with bilateral agreements and have served to greatly unify the policy competences of the ACs (López Guerra, 1993: 32-5; Agranoff, 1999: 107-12). The role of political agreements has also been very relevant in the process of attecation of resources between the different tiers of government. This is quite a politicized issue in Spain that has been the cause of much tepsion between the State and some ACs (especially Catalonia and the Basque Country).

This system of bilaterałand multilateral agreements serves to give weight to the ACs' opinions (in the alloeation of resources. Such agreements are an essential part of cooperative federalism (Wiltshire, 1980: 355ff). However, it bas geen widely gritycized for its lack of transparency, as those agreements take plaee behind closed doors and the results are only partially made public. This is the so-called 'executive federalism' that may give rise to a deficit of democracy (Wiltshire, 1980: 369; Ramallo Massanet and Zornoza Pérez, 2000). It has often been argued that most of this political discussion should take place in the Senate, which, at least in theory if not in practice, is the representative chamber of the ACs (García Morillo, Pérez Tremps and Zornoza Pérez, 1998).

Another frequent criticism of the agreements is that they have modified the rules for the allocation of resources established in the Constitution and in the laws to benefit those ACs in a better position to negotiate. These criticisms mainly arose after Convergència $i$ Uniò (CiU), the Catalan nationalist party, helped each of the two main national political parties, the Partido Socialista Obrero Español (PSOE) and the Partido Popular (PP), build a sufficient majority to govern in 1993-96 and 1996-2000 respectively. In exchange, the $\mathrm{CiU}$ sought, and obtained, a revision of the common financing system. ${ }^{4}$ However, as the subsequent reforms in the system applied to all ACs, not only Catalonia, this second criticism seems unfounded. 
THE ROLE OF THE CONSTITUTIONAL COURTIN THE DEVOLVED FINANCING SYSTEM

The rulings of the Constitutional Court have played a significant role in the definition of authority in the State of Autonomies. Taking into account that the vast majority of the matters listed in the Constitution are actually shared between the State and the ACs, it is not hard to imagine that this has been a source of permanent conflict between these two tiers of government. The court, as the only body competent to resolve such conflicts, has undertaken a very important task in the evolution of the State of Autonomies (López Guerra, 1998).

In taxation matters, there have been some relevant opinions that have reinforced the ACs' spending power (13/1992; see Ramallo Massanet, 1993); declared void AC taxes because trey were similar to State or municipal taxes $(49 / 1995,289 / 2000)$; and established the right of ACs to establish taxes, provided they do so in matters that fall within their scope of competence (37/1987, 186/1993) (Ortiz Catte, 2001.28ff).

This role has been reinforced by the unfinished nature of the different provisions regarding regional autonony established in the Constitution, and by a certain 'didactic' tenderey of the court to fully explain and thus serve to clarify the rules governing the State of Autonomies. Moreover, the court has often ruled in fay of the ACs, which in the first years of the decentralized mode was almost revolutionary in a country with such a long tradition of eentralization_López Guerra, 1998: 263-4). However, it is probably time thet it played a secondary role in the shaping of the State of Autonomies, in favour of a stronger role for parliamentary authorities. At present, if is becoming almost routine in Spain to discuss any Law of certain jumportance in two forums, a first debate in the Parliament, a second, and decisive one, in the Constitutional Court' (López Guerra, 1998: 263).

\section{ASYMMETRY: THE EXISTENCE OF TWO FINANCING SYSTEMS}

One of the main features of the Spanish fiscal decentralization model is the radical asymmetry that exists between two groups of ACs. On the one hand, the financing systems applicable to the foral ACs are known as Concierto (Basque Country) and Convenio (Navarra) systems. Both these terms translate into English as 'agreement'. The main characteristic of this kind of system is that it entails a maximum level of taxation autonomy, which means these two ACs have powers to pass legislation, with only a few limitations, ${ }^{5}$ on the main taxes of the Spanish fiscal system. Because the State is still responsible for the provision of some public functions or 
services within the territory of these two ACs, it is entitled to receive a certain sum of money from them, known as the 'Cupo' (quota).

In contrast, the so-called 'common system', which applies to the rest of the ACs, is quite the opposite of the Cupo. For reasons to be examined later, the main difference lies in the fact that, under the common system, the ACs have very limited taxation powers, which results in a greater financial dependence upon the State. Hence, most of their revenues are provided by the State, in the form of transfers.

For the ACs within the Cupo system, the revenues deriving from taxes represent 94 per cent of expenditure, while transfers from the State represent less than 1 per cent in the case of the Basque Country, and less than 3 per cent in the case of Navarra. ${ }^{6}$ For the common-system ACs, transfers still represent more than 60 per centof their revenues. Taxes only represent about 20 per cent; within this category, ceded taxes, which still operate, in practice, as a mere transfer of funds as most ACs have exercised their powers in a very limited way, represent about 20 per cent. ${ }^{7}$

It is commonplace in the fiscal federatism lifetature to refer to 'Vertical Fiscal Imbalance', abbreviated as VKI and also known as 'fiscal mismatch', 'fiscal gap' or 'revenuegap'. This situation arises when one tier of government - usually the state - has a greater power to obtain revenues than it actually needs for the exercise of its assigned level of authority, while the other - usually consisting of sub-national governments - is in the opposite situation (Oates, 1977: 16; Boadway and Hobson, 1993: 28ff; Boadway, 2000: 46ff). This greakes an imbalance that must be resolved in order to guarantee the sub-national governments the autonomy required for the exercise of their authority. The problem is easily understood and conflicting parties - the State and sub-national governments - normally agree that it must be resolved and that the allocation of resources must be 're-balanced'. Conflict usually arises when deciding which of the different possible solutions should be used.

Briefly, VFI imbalance can be solved either through transfers from the state or through a reassignment of taxation powers. In practice, a mix of the two is typically used, so that most sub-national governments receive financing in the form of both transfers and their own taxes. When subnational governments receive financing almost exclusively in the form of transfers, an incentive is created to spend those monies in a less responsible way. The idea is simple and similar to the 'moral hazard' problem. It is easier for governments to spend money when (a) they do not shoulder the political burden of having to raise it (i.e. establishing or raising taxes), and (b) there is no need for them to explain to voters/taxpayers the relationship between monies raised and monies spent (Boadway, 2000: 51). In other words, the situation creates a lack of accountability that may not be 
advisable. This has been, and to a certain extent still is, the situation for common-system ACs.

Debates about the ACs' fiscal responsibility have become one of the main issues in the relationship between the State and the ACs. There is a certain generalized agreement in that it is fiscal responsibility 'at the margin' (Heald and Geaughan, 1996: 173ff; Boadway, 2001: 112), as opposed to the exact equivalence of expenditure and own revenues, that is the objective to be attained. Giving sub-national tiers of government responsibility to obtain monies in addition to what they obtain in the form of transfers has been considered fundamental to any decentralization of powers (Castells Oliveres, 1988: 75; Ramallo Massanet, 1988: 534-5; Zornoza Pérez, 1996: 20ff; McLure, 2000: 634ff; García-Milá and McGuire, 2003; Ruiz Almendral 2003a).

Moreover, the transfer of at least some taxation powers to such subnational tiers of government has been considered essential in order to reinforce a certain level of political autonomy. this sense, it has been said that the most essential principle in matters gf taxation is the guarantee that the institutions establishing them have a demociatic representation, which has been traditionally expressed through the maxim 'No taxation without representation'. The basic principe in the decentralization of authority in a multi-level government may be expressed with another maxim: 'No representation without taxation' (Heald et al., 1998: 28ff).

In Spain, VELaccurs in both the Cupo and the common system. In the first case, it favours the historic XCs. The opposite happens in the common system, where most ACs still receive transfers from the State to facilitate the execution of their competences. Thus, put simply, it is possible to say that in the Cupo system. ACs finance the State, while in the common system exactly the opposite bccurs. This situation is bound to change in the next few years, as there have been some legislative reforms whose aim was to increase the common-system ACs' fiscal responsibility, and thus decrease their financial dependence upon the State (Zubiri, 2000a: 77; García-Milá and McGuire, 2003).

The question is, then, how is it possible to maintain such different financial systems among sub-national entities within the same country? As can be easily imagined, the mere existence of such asymmetries has been, and still is, the cause of much political discussion. The Constitution recognizes the existence of certain 'historic rights'. Thus, its first supplementary provisions state that 'the Constitution protects and respects the historical rights of the foral territories'. However, to some authors, this provision does not permit the existence of totally different financing rules (Medina Guerrero, 1991: 82ff). It has also been argued that it is not feasible to maintain such asymmetry in the long term as this will have a 
negative impact on the efficiency of the system, mainly because it would lead to increasingly divergent tax systems (García-Milá and McGuire, 2003).

Whether or not the Cupo system could be extended to the other ACs has been the subject of much academic debate. There seems to be a certain consensus that it would not be economically sustainable, as it would entail the loss of the most important taxes, and their revenues, by the State (Castells Oliveres, 2000b; Zubiri, 2000b: 137ff). Some observers have calculated that if the system were applied to all common-system ACs, all of them except the two poorest (Andalucía and Extremadura) would gain (Zubiri: 2000b, 139). Others come to the same conclusion but attribute it not to greater tax powers, but in certain revenue advantages that lie in the original calculation of the Сupo and that persist, despite apparent inaccuracies, for political reasons (García-Mina and McGuire: 2003).

THE COMMON FINANCIAL SYSTEM

The Allocation of Resources Under the Constizution: The Role of Transfers and Taxes in the Financing of $A C$

The small proportion of own tax revenues in the financing of the commonsystem ACs results in a substantial lack of fiscal responsibility. This situation derives both from the fact that they have limited taxation powers, and from their insufficientuse of the powers that they already have. This situation is barelyconsistent with the larger responsibility that the ACs have in other areas, as has been often pointed out (Rodríguez Bereijo, 1985: 71; Zornoza Pérez, 1987: 971y 2; Castells Oliveres, 1988: 129ff, and 2002: 14ff; Solé-Vilanova, 1990. 350ff; Ramallo Massanet, 1993; García-Milá and McGuire, 2003; Ruiz Almendral, 2003a).

This debate has eventually led to substantial reforms of the ACs' financing system. The main objective has been to increase the ACs' powers to establish taxes, thus changing the present situation where they are still seen by taxpayers as 'fairy godmothers' who offer services to citizens without asking for monies in exchange (the taxation role of 'wicked stepmother' being played by the State).

In accordance with the recognition of autonomy, or, stated more accurately, the recognition of the right to be autonomous, the Spanish Constitution grants ACs 'financial autonomy for the development and execution of their authority'. The Constitutional Court has interpreted this as their right to have sufficient means for carrying out the competences that fall within their scope of authority, as well as the right to manage those means without any undue conditions imposed by the State. ${ }^{8}$ 
Apart from stating this principle of financial autonomy, the Constitution establishes a list of resources that will constitute the ACs' income. This list includes almost all kinds of possible existing resources. Thus, they may obtain revenues from: ceded taxes; surtaxes on existing State taxes; their own taxes; public debt; and transfers (Section 157.1). Furthermore, the Constitution clearly recognizes and guarantees taxation powers to the ACs (Section 133.2). However, they must abide by the rules established by the State. In Section 157.3, the Constitution allows the State to approve a special law (ley orgánica) regulating both how these resources will be distributed among ACs and the limits for the exercise of their financial power on the resources. This implies that the State is given the power to both limit and control the financial autonomy of the ACs. This is probably inconsistent with the recognition of the right to autonomy granted to the ACs, as has often been pointed out (Zornoza Pérez, 1987: 971-2; Castells Oliveres, 1988; Ruiz Almendral, 2003a). The state has made use of this possibility and approved a set of laws that greatly limit the financial autonomy of the ACs. ${ }^{9}$

Most relevant is the Special Law for the Financing of the Autonomous Communities, Law 8/1980 (Lex Qxánica)de Financiación de las Comunidades Autónomas - hereafter, the LOFCA). Good examples of these limits are those established ønyhe creation of new taxes by ACs (discussed later). Although it is not (atways clear whether it is the limitations on establishing ney taxes or the unwillingness to withstand the political consequences of increasing the tax burden that has deterred ACs from creating new taxes, the existence of such limits underlines the importance of intergovernmental transfers in Spain. When the level of tax autonomy is so low, the possibilities/for ACs to obtain their own resources are scarce; hence the need for transfers from the State. This situation also explains the substantial imbalance between the common-system ACs' autonomy of spending - which has been strongly supported by the Constitutional Court - and their limited power to raise their own revenues.

Therefore, since the beginning of the State of Autonomies, transfers have played a far more important role than own taxes, which has resulted in the ACs' financial dependence on the State. For most of them, transfers still represent more than half of their revenues. Moreover, if we take into account that ceded taxes are closer to being a transfer than a tax revenue, this percentage can amount to as much as 80 per cent of their current revenues.

The transfers received by the ACs have traditionally been based upon need. According to the LOFCA, the cost of the devolved powers would be calculated and a given amount would then be transferred to the ACs. In reality, the cost was actually never calculated but rather negotiated in 
bilateral commissions (between the State and each AC); these would meet behind closed doors and agree on a certain amount. The reason for this is that the existing accounting systems of the State were inadequate for such calculations, so the actual cost of the transferred services was never actually determined (Generalidad de Cataluña, 1985: 35ff; Castells Oliveres, 1988: 138ff; Monasterio Escudero and Suárez Pandiello, 1993: 17ff; Zornoza Pérez, 1987 and 1996). This continuous negotiation was also the subject of sharp criticism. Apart from the argument that it was undemocratic, from a financial perspective it was deemed to create inequalities as, eventually, those ACs whose bargaining position was weaker would get less monies to exercise the powers that fall within the scope of their authority.

Conditional transfers have a large relative weight in the financing of ACs. As in many other decentralized states, thejr mere existence has often given rise to controversy. According to the Gonstitutional Court's rulings, transfer of monies from the State to the ACs must be unconditional when its objective is to pay for classes of matters that fall under the authority of the ACs. Otherwise, according to the Couphe spending power of the State would intrude, serving indirectly as a way of dontrolling the ACs' activities (Opinion 13/1992). While the case taw may state this general principle, in practice this has been a continuous source of tension between the ACs and the State. The main claim of the ACs has been that the State puts conditions on the transfers of monies that go farbeyond its authority, thus intruding into their powers Examples include the provisions in the State's budget law that clearly state which institution/organ of the AC should administer the monies, in effect predetermining how the money should be spent. ${ }^{10}$

This financialdependence of ACs was not regarded as a problem in the early years of devoluxion. Back then, the ACs were regarded with a certain distrust by citizens and some of their attempts to establish new taxes were emphatically rejected by voters. ${ }^{11}$ As the ACs gained more powers, their financial needs grew substantially and a greater expansion of the transfer system was needed. Thus, the fast-lane ACs became the most financially dependent. Debates about the ACs' fiscal responsibility became one of the main issues in the relationship between the State and the ACs. Once the State of Autonomies had become a reality, the idea that the ACs should have more say in taxation matters became commonplace.

\section{Limited Powers of ACs to Establish New Taxes}

Although the Constitution (Sections 133 and 157) bestows taxation powers upon the ACs, the LOFCA imposes severe limits on the creation by them of new taxes. The most important limitation is the prohibition of double taxation (Sections 6.2 and 6.3), which prevents autonomous taxes from being similar to taxes created by the State and the municipalities. As these 
had already established taxes on most of the imaginable sources of revenues, little tax room was left for ACs (Zornoza Pérez, 1987[??] and 1996). The existing tax room was traditionally occupied by the State and the municipalities, and this did not change when the ACs were established.

Therefore, despite constitutional provisions that guarantee to ACs the power to establish taxes and financial autonomy (Section 156.1), the limits established by the State have led to a system in which taxation powers remain mostly in its hands. Generally, the establishment of new taxes is not a very attractive option for ACs. On the one hand, most of the ACs' taxes are very costly to administer and do not generate much revenue. On the other, almost every time an AC establishes a new tax, the State challenges it before the Constitutional Court. ${ }^{12}$ Such prohibitions equally affect the creation of new taxes by the foral ACs. However, because they hold extensive powers on most of the relevant toxes the Concierto or Convenio taxes), they do not need to create new ones. Khis situation inspired the 1997 and 2002 reforms of the common system.

The 1997 and 2002 Reforms of Ceded faxes

The main goal of these reforms was make/ACs more involved in the establishment of taxes and thus mpre directly accountable to their taxpayers for the monies they spend. This has been done through a reassignment of tax powers, which took place beween 1997 and 2002. These reforms consist of the sharing of sone tax room that until then had been occupied solely by the State. This is done though a type/of resource called a 'ceded tax'. The term 'ceded' is not quitedaccurate, as it was not the tax but rather its yield that was ceded to the ACs. Thus, until 1997, ceded taxes were State taxes whose yield was granted to ACs according to the taxes paid within their territory. Due to powers delegated by the State, ACs had also taken on the responsibility for administering these taxes.

Ceded taxes were therefore virtually a kind of transfer, by which some of the taxes 'owned' and entirely regulated by the State accrued to, and were administered by, the ACs. They differ from transfers in that the ACs may receive a 'bonus' in some cases. Thus, if the actual yield of the tax is greater than what had been forecast by the State, the AC receives the difference, though if it is less the AC receives the initially forecast amount. However, an increase of the yield may or may not be a consequence of a better tax administration; for example, it may be due to economic conditions. Therefore, this bonus only partially serves as an incentive for ACs to administer ceded taxes more efficiently. ${ }^{13}$ On the other hand, the ACs' decision-making powers over these kinds of taxes were almost non-existent. Until 1997, ceded taxes were a type of resource conceptually closer to a transfer. 
TABLE 3

CEDED TAXES AS AT 1 JANUARY 1997

\begin{tabular}{lccc}
\hline Ceded tax & $\begin{array}{c}\text { AC share } \\
(\%)\end{array}$ & Administration & $\begin{array}{c}\text { Legislative powers that ACs } \\
\text { may assume }\end{array}$ \\
\hline Personal income tax & 33 & State & $\begin{array}{c}\text { Tax rates (must have same number of tax } \\
\text { brackets as the State tax) } \\
\text { Tax credits, under certain conditions } \\
\text { Tax rates (must have same number of tax } \\
\text { brackets as the State tax) } \\
\text { Minimum threshold }\end{array}$ \\
$\begin{array}{l}\text { Tax rates } \\
\text { Taxes on transfers } \\
\text { and official documents }\end{array}$ & 100 & 100 & $\begin{array}{c}\text { ACs } \\
\text { Gambling taxes }\end{array}$
\end{tabular}
giving ceded taxes quiter different meaning than they had previously had. Thus, the poyer to regulate some aspects of these taxes - mainly tax brackets, tarrates and some tax credits - was conferred on the ACs. What until 1997 had been \& form of transfer then became a form of tax sharing (Zornoza Pérez, 1997; Ruiz-Huerta and López Laborda, 1997; Castells Oliveres, 2000b; Ruiz/Almendral, 2003a: 107ff).

As shown in Table 3, the powers of ACs are not uniform across ceded taxes. Depending on the tax, the yield will totally or partially accrue to the ACs, which may or may not take on legislative powers and be in charge of the administration of the tax.

The ACs are given the option to choose whether they want to exercise their regulatory powers. If they fail to do so or decide not to exercise such powers, the State regulates every aspect in that $\mathrm{AC}$. If an $\mathrm{AC}$ decides to pass legislation modifying the above-mentioned authorized aspects over any ceded tax, it may do so by enacting legislation which will then substitute for State law in those areas where the AC can legislate. For instance, in the case of the wealth tax (where ACs may establish whatever tax rates they choose), State legislation on tax rates will be applied to residents in those ACs that decide not to establish their own tax rates. The way that this option has been structured - and the fact that the State still guarantees to ACs lump-sum grants allocated on the basis of 
TABLE 4

CEDED TAXES AS AT 1 JANUARY 2002

\begin{tabular}{|c|c|c|c|}
\hline Ceded taxes & $\begin{array}{l}\text { AC share } \\
(\%)\end{array}$ & Administration & $\begin{array}{c}\text { Legislative powers that ACs } \\
\text { may assume }\end{array}$ \\
\hline Personal income tax & 33 & State & $\begin{array}{l}\text { Tax rates (must have same number } \\
\text { of tax brackets as the State tax) } \\
\text { Tax credits, under certain conditions }\end{array}$ \\
\hline Wealth tax & 100 & ACs & $\begin{array}{l}\text { Tax rates } \\
\text { Minimum threshold } \\
\text { Tax credits }\end{array}$ \\
\hline Death and gift taxes & 100 & ACs & $\begin{array}{c}\text { Deductions (mainly, for family } \\
\text { circumstances) Tax rates } \\
\text { Deductions and tax credits } \\
\text { Tax administration regulations }\end{array}$ \\
\hline $\begin{array}{l}\text { Taxes on transfers } \\
\text { and official documents }\end{array}$ & 100 & $\mathrm{ACs}$ & Tax rates \\
\hline Gambling taxes & 100 & ACs & nptions \\
\hline Value added tax & 35 & & None \\
\hline Excise duties & 40 & & None \\
\hline Tax on wine & & State & None \\
\hline Tax on electricit & & State & None \\
\hline Tax on vehicles & & ACs & $\begin{array}{l}\text { Tax rates (under certain conditions and } \\
\text { limits) }\end{array}$ \\
\hline Special tax on gas & & ACs & $\begin{array}{c}\text { Tax rates (under certain conditions and } \\
\text { limits) } \\
\text { Tax administration regulations }\end{array}$ \\
\hline
\end{tabular}

historical shares in State transfers - serves to create a strong disincentive for ACs to use their new taxation powers. Evidence of this disincentive is the fact that, since 1997, the ACs have mainly used their powers to create new fiscal benefits (Ruiz Almendral, 2002a: 473ff; 2003a: 301-434).

In July 2001, the ACs and the State agreed to broaden the scope of these ceded taxes. As a result, the ACs' legislative powers for some of these taxes are now greater and new taxes have been ceded to them. The new powers over the ceded taxes vary widely, depending on the tax. In some cases, the ceded tax operates substantially as a transfer (as in the Value Added Tax) but in others, the broad scope of the powers granted makes the tax very similar to an autonomous tax (as in the case of gambling taxes). The position as at 1 January 2002 is shown in Table 4. 
TABLE 5

COMPARISON OF LEGISLATIVE POWERS OF COMMON-SYSTEM AND FORAL ACS

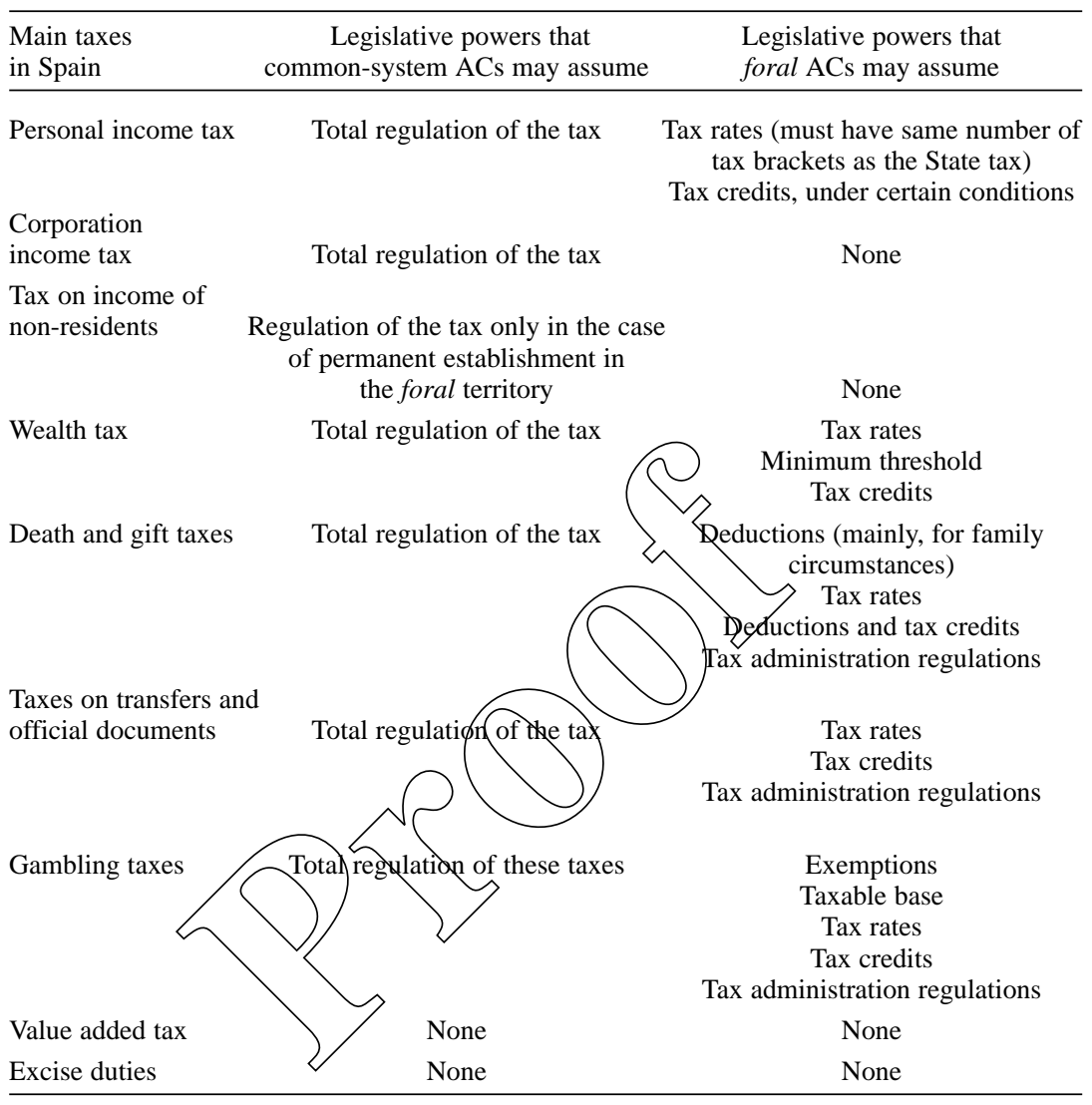

This reassignment of taxation powers constitutes the most important tax reform since the State of Autonomies became a reality. Under the new regime, common-system ACs have substantially increased their taxation powers. Although the gap between the powers of the foral and common ACs remains quite large, it has certainly been reduced by the reform. If the tendency continues, the possibility that the two systems end up converging should not be completely ruled out. Such convergence derives mainly from the common-system ACs' newly acquired taxation powers. Until 1997, only foral ACs could pass legislation and control the main taxes of the system (such as personal income or corporation income taxes). Since then, common-system ACs have gradually gained access to most important tax 
bases, excluding corporation income taxes. Although the gap is still wide, for common-system ACs can only regulate certain aspects of some of these taxes while foral ACs may regulate most elements of the said taxes except for certain aspects, the tendency is a degree of convergence. However, when we compare the powers that the common-system and foral ACs hold on the main taxes of the taxation system, it is clear from Table 5 that a profound asymmetry prevails.

\section{The Role of Transfers: A System Still Largely Based Upon Need}

As much as the taxation powers of both financing systems are becoming closer, the financing rules governing them remain radically different. The financing of common-system ACs is still largely based upon need. Thus their newly acquired fiscal capacity on ceded taxes, which represents a considerable change to the former situation where ACs' egys ative powers on taxes were clearly residual, is not sufficiently taken into account. The common system establishes a set of revenue guarantees aimed at coverting the potential risk that the exercise of taxation powers usually entais. Put simply, while revenues in the foral systems accrue to the ACs on a strictly derivation basis, in the common system, the State guarantees minimume revenues also on ceded taxes.

The financing system is enfifely regulated in a state law $^{14}$ for all 15 common-system ACs. In brief, the law prescribes that all ACs shall receive an amount sufficient to firance their atthority. This amount, named 'masa homogénea', is formed oy ceded taxes and general grants from the State, all calculated relative to the base year 1999. This way, it is guaranteed that no $\mathrm{AC}$ will receivg less han under the previous system. The way these monies are distributed among the 15 common-system ACs includes a set of guarantees and adjustments in order to take into account certain redistributive criteria, such as density of population and relative income.

If an $\mathrm{AC}$ decides to increase or decrease the tax burden of its ceded taxes, this will be reflected in the total budget received from the State, which will then vary accordingly. However, there is no mechanism to incentivize ACs to exercise their taxation powers, as they still obtain the revenue of ceded taxes, even when they do not actually regulate any aspect of them. That is, the financial incentive for ACs to use their powers over those ceded taxes they control is weaker than the political incentive not to increase the tax burden of their citizens because a substantial amount of revenue is already guaranteed from ceded taxes they do not control. This explains why most of them have preferred to establish tax credits and tax benefits, as opposed to increasing the tax burden - that has, so far, only occurred in the cases of gambling taxes, capital transfers tax and stamp duty.

It would be feasible in Spain, and would constitute a good way to increase the common-system ACs' exercise of fiscal responsibility, to adopt 
a formula that took into account their actual fiscal capacity (Ruiz Almendral: 2003b). That would involve actually measuring their potential to obtain additional revenues, and taking that into account when designing the transfer systems. The idea would be to establish a system similar to the Canadian 'representative tax system'.

\section{THE CUPO SYSTEMS OF THE BASQUE COUNTRY AND NAVARRA}

The functioning of the financial system for the foral ACs is radically different to that for the common-system ACs. Under the Cupo systems, the foral ACs run all the risk themselves, and no revenue guarantee is provided by the State. Presumably, this status is still attractive for these communities, as they are richer than the Spanish average. Angther feasible explanation is that, as some claim (see above), the Cuke has never been properly calculated, the result being that these communities (Basque Country and Navarra) may actually be paying less for the same services than the (common-system) rest. This continues to be of the main objects of tension between the Basque government and the State government.

Assignment of Taxes

There are two main differences between the Navarra system and the Basque Country system. First, the Conventio of Navarra is valid for an indefinite period, while the Conclerto of the Basque Country must be renegotiated every five years 15 by the Joint Committee (Comisión mixta) on the Economic Agrement. This committee is made up of 12 members: one per provincial councik (diputación foral), three from the Basque government, and six from the State government. So far, since the approval of the Spanish Constitution, there have been five Cupo laws, in force during the following periods: 1982-86, 1987-91, 1992-96, 1997-2001 and 2002-06. ${ }^{16}$ The second difference is that, unlike any other $\mathrm{AC}$, the Basque $\mathrm{AC}$ has legislative authority over municipalities. This includes the right to establish and regulate local taxes, within a very flexible framework established by the State.

The origins of the Basque Concierto can be traced back to the thirteenth century, though a more direct precedent of the present system is the Law of 21 July 1876. During the Spanish Civil War, the Concierto was suspended for Bizkaia and Gipuzkoa, two of the three provinces that form the Basque Country. During Franco's dictatorship, only the third province, Álava, was allowed to keep the Concierto system. The enactment of the Basque Country's Statute of Autonomy in 1979 - known as the Guernica Statute restored the Concierto to the whole Basque Country, which was made effective under the Law 12/1981, 13 May (Medina Guerrero, 1991; Alonso 
Olea, 1995). The Basque Concierto underwent a substantial reform in 1997 (Law 38/1997), which resulted in a certain increase of this AC's leeway in the exercise of its taxation powers, as some of the limits for such exercise were removed.

Navarra's system dates back to the Law of 16 August 1841. Under the present Constitution, it is regulated by Special Law 13/1982, 10 August (Ley de Reintegración y Amejoramiento del Régimen Foral de Navarra) and by Law 28/1990, 26 December, which contains the details and calculation of Navarra's Cupo. Although the description below of the operation of the Cupo system refers specifically to the Basque Country, that for Navarra is quite similar.

The Cupo systems entail that the Basque Country and Navarra have the right to have their own tax systems, which inclydes most of the powers to regulate and administer the main taxes that nould be held by any treasury. The agreement includes a set of provisidns that aim to guarantee an adequate level of harmonization - not hompgeneity - between these systems and the State's. The foral must, infer alia: respect the solidarity principle enshrined in the Constitution (Sections 2 and 156.2); establish their tax legislation with regard to the general taxation structure of the State (which shall therefore nqt be distorted by the exercise of taxation powers by the ACs) $;{ }^{17}$ and maingtain general tax burden 'equivalent' to the State's. This last provision is certainly ambiguous: there is no official interpretation of what exacly dan be considered to be a non-equivalent level of tax burden (Zubiri, 2000a: 51fy).

In the case of the Basque Country, the authority on taxation matters is exercised not by the $\mathrm{AC}$ itself, but by the governing bodies (known as Diputaciones forales of the three foral provinces: Álava, Bizkaia and Gipuzkoa. Their treasuries regulate, levy and administer all the Basque Country's taxes. The Basque Parliament is then in charge of enacting the pertinent provisions in order to guarantee a certain level of harmonization among the three bodies (including both their legislative and executive powers). In this regard, it is important to point to the existence of the Basque Tax Coordination Agency (Órgano de Coordinación Tributaria de Euskadi - OCTE), created in 1989 (by Law 3/1989, 30 May). In this agency there are representatives of the three provincial councils and of the Basque government. Among other activities, the OCTE publishes the Basque Treasury's Integrated Annual Report, ${ }^{18}$ where all the data concerning the three treasuries, as well as other information, can be found.

The Concierto or Convenio taxes are all the main taxes of the Spanish tax system, such as personal and corporation income taxes, the wealth tax, the death and gift taxes, the capital transfer tax and stamp duty. Those taxes that are harmonized, in a more or less precise way, by European Union (EU) 
regulations also belong to the Basque Country's provinces, in that they are in charge of their collection and obtain their revenue, though they can only be regulated by the State. Such is the case with VAT, excise duties, and the tax on the income of non-residents.

The structure and provisions of the Concierto or Convenio taxes do not differ greatly from the State's taxes. Nevertheless, some substantive differences may be pointed out. For personal income tax, there are slightly higher rates and greater progressiveness, as well as greater tax credits for family circumstances. The tax rates are also lower for corporation income tax (35 and 32.5 per cent, respectively), while the tax reliefs are higher. Greater differences can be found in the death and gift taxes, where there are substantially lower rates and a general exemption for close relatives. Since the year 2000, there is a general tendency among the common-system ACs to lower this tax, following the same pattern as the foral ACs. It would not be surprising if this tax disappears, such as has happened in other federations such as Canada (Boadway and Hokson, 1999: 48), as a consequence of a generalized tendency towe it Ruriz Almendral: 2003a, 350ff). Finally, slightly lower tax rates haye been established for the capital transfers tax and stamp duty.

The Calculation of the Cupo

The Cupo is directed towards paying for the State's general expenditures on certain areas of mationa interest, such as foreign affairs, defence and the army, customs and general transport. The method for calculating the Cupo is regulated by the Economic Agreement Act and the Five-year Cupo Act 2002-06. ${ }^{19}$

The amount of the Cupo (C) to be paid is determined by first determining the fiscalcapacity ratio or 'attribution rate' (i), calculated as the percentage which the foral AC's revenue bears to that of the State. This percentage is then applied to total non-assumed charges for the foral AC. According to section 52 of the Economic Agreement Law, 'to determine the total amount of the said charges [non-assumed charges], the entire State Budget allocation corresponding to the competences assumed by the AC ... shall be deducted from the total State Budget expenditures'. ${ }^{20}$

For the 2002-06 period, the attribution index has been established as 6.24 per cent. The resulting quantity (gross $\mathrm{Cupo}$ ) must also undergo certain adjustments, in order to take into account other variables. Thus, for example the attributable portion of the deficit figuring in the general State budget is subtracted from the Cиро. Other compensations include that which corresponds to taxes not covered by the Economic Agreement. After such adjustments and compensations, we obtain the final Cupo (net Cupo) ${ }^{21}-$ see Figure 1 
FIGURE 1

CALCULATION OF THE CUPO FOR THE BASQUE COUNTRY AC FOR BASE YEAR 2002 (THOUSAND OF EUROS)

Calculation of Cupo (for base year 2002)

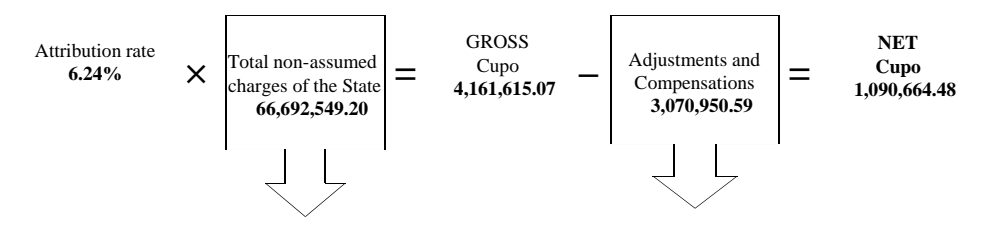

$$
\begin{aligned}
& \text { - Total State Budget expenditure } \\
& \text { ( } \mathbf{1 4 4 , 1 0 4 , 1 6 5 . 0 8 )} \quad \text { minus } \\
& \text { - Total State Budget allocation corresponding } \\
& \text { to competences assumed by the AC } \\
& (\mathbf{7 7 , 4 1 1 , 6 1 5 . 8 8})
\end{aligned}
$$

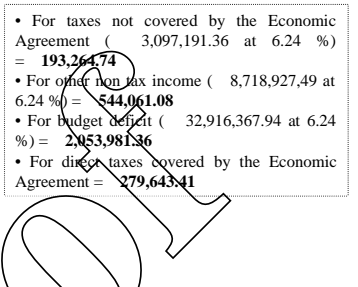

Source: The author, with data provided by the Annex to the Five Year Quota Act, which can be found in English at: http://www.eph kadinet/4utogobierno/concierto_i.htm

\section{The Impact of EU Membership on the AC' Taxation Power}

Belonging to the EU has had important consequences for the distribution of authority in eyery member state yith multiple levels of governments (Pérez Tremps, 2000. 107218). Spain is no exception, and European integration poses a very importan limitation to the exercise of taxation powers by the ACs. Obviously, such consequences are greater for the foral ACs, due to their wider taxation powers.

In this regard, there have been some conflicts when the EU has questioned both the generally lower tax burden of the tax system in the Basque Country and Navarra, in comparison to the common system, as well as the very existence of such different tax regimes within the same country. A good example of this is the European Commission Decision No. 93/337/CEE of 10 May 1993, which stated that some of the tax measures in the Basque corporation income tax may be inconsistent with the right of establishment (Section 43, EC Treaty) and may also fall under the category of 'state aids' (Section 87, EC Treaty). Of special interest are the conclusions of the Advocate-General, Antonio Saggio, presented on 1 July 1999 in the accumulated cases C-400/97, C-401/97 and C-402/97, also relating to corporation income tax.

In the few cases where the Constitutional Court has had to deal with the Cupo system, it has clearly stated that it is consistent with the Constitution 
(inter alia, in Opinion 181/1988). However, a recent opinion of the same court (96/2002) may have started a new line of thought that would clearly limit the importance of the constitutional recognition of historic rights. This opinion is very complicated, mainly because it does not state clearly, but rather 'suggests', as obiter dicta, that a divergent tax system may not comply with the principle of equality stated in Section 14 of the Constitution.

In this case, brought by the AC of La Rioja, which claimed the foral ACs were engaging in fiscal competition, the Constitutional Court ruled that the foral autonomy itself is not sufficient to render tax provisions admissible, and that the equality rights are as much part of the Constitution as are the special provisions that guarantee the historic rights. The relevance of this opinion goes far beyond the actual decision $\operatorname{taken}^{22}$ because, for the first time ever, the Court seems to call into question the existence of such different systems. This decision has been the source of much controversy, as indicated by the fact that it was rejected by half of the court's judges and could therefore only be approved because the president was in favour. It is very likely that this opinion would not hake been adopted had the European Commission not questioned the forat systems oreviously.

As for the common-system ACs, the main impact of the EU is that, according to Section 19 of the LOFCA the legislative powers over ceded taxes may be revoked ar any time by the State on the grounds of the European harmonization process.

\section{CONCLUSION}

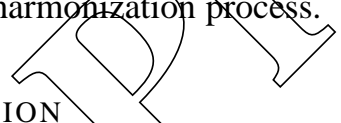

The decentralization process in Spain has been rapid and, generally speaking, quite successful. Authority has been devolved to ACs in an orderly fashion and this new tier of government has been well accepted by citizens.

Nonetheless, some issues remain unresolved. Thus, while political agreements are a necessary part of the cooperative federalism model of Spain, the Senate should also play a role in the process. This will not be possible unless there is a substantial reform of this institution. This reform is now more necessary than ever, as only an adequate representative chamber can guarantee that ACs will have a say in the EU policies that affect them. Moreover, as important as the opinions of the Constitutional Court may have been in the clarification of the devolution process, it is time that most of the conflicts were discussed and resolved in Parliament, thus decreasing what has been known as a judicialization of the State of Autonomies.

As for the level of fiscal responsibility, despite the important reallocation of taxation powers that occurred in 1997 and 2002, there 
prevails a large imbalance between the authority exercised by the commonsystem ACs and the foral ones. The fact that the Cupo system does not envisage any guarantee of minimum revenues partially serves to explain this situation.

\section{NOTES}

1. Of course, even the term 'federation' is not uncontroversial. While for some it is necessary that the decentralization of powers derives directly from the constitution in order to categorize a country as federal (Beer, 1997: 22), to others only those countries where subnational governments actually exercise their powers may fall into the said category (Bird, 1994: 295). It is so difficult to find two similar federations that the term must be used with the utmost care (Watts, 1994).

2. Thus, under Section 148.2, slow-laners may take on competences, inter alia, on the following areas of authority: forestry, cattle, fishing, housing, roads, non-commercial ports and airports, environmental protection, libraries, nuteums, conservatoires, promotion of tourism and sports. Fast-laners have access to all these plus education and health.

3. In 2000, PP obtained absolute majority, which enabled it fo govern without the need of CiU.

4. CiU's support of the PSOE was the origin of the shasinge of a percentage of income tax for some ACs (Agreement of 10 October 1993). CiY's suppoyt forthe PP was the origin of the 1997 reform (Agreement of 23 Sseptember 1996).

5. Such limitations are established in the laws regulating the Convenio and Concierto, and basically refer to the need to maintain a certain lekel of harmonization with the State's tax system. They are, however, establishef in quite broad terms, which for example allow the Basque Country to establish corporation tax credits that differ broadly from those of the State.

6. The source for these data are Organode Coordinación Tributaria de Euskadi (2002), p.81, and Liquidación de Presupuestos de las Comunidades y Ciudades Autónomas (2003). These can be found at yww.estadier.minkac.es/ (accessed ???)

7. Source: Liquidación de Presupuestos le las Comunidades y Ciudades Autónomas (2003). This can befound ax: http://www.estadief.minhac.es/ (accessed ???)

8. Sentence Opinion $13 / 1992$ contains a good summary of the Court's case law in this matter. As with the rest of the opinions, this can be found at www.tribunalconstitucional.es (accessed ??)

9. Recently, the State has passed a law to curb the deficit of ACs, and thus comply with European Union requirements. This is the General Budget Stability Law (Ley 18/2001, 12 December, General de Estabilidad Presupuestaria) and it imposes new limits on the creation of public debt by ACs. This law has been challenged before the Constitutional Court by the PSOE, but it will be some time before a ruling is made.

10. Opinion 13/1992 contains a good summary of such measures.

11. In this respect, what happened when, in the early 1980s, the AC of Madrid decided to establish a surtax of about 3 per cent on the State's personal income tax is significant. Many argued that such a surtax was unconstitutional and it was challenged before the Constitutional Court. In Sentence Opinion 150/1990, it the Court declared it perfectly valid. However, the law was that established it never implemented and was then repealed; the PSOE Government that had established it lost the next elections in favour ofto the PP.

12. Recently, Catalonia established a tax on big large commercial surfaces areas (Impuesto sobre grandes establecimientos comerciales) by the Law 16/2000, of 29 December. No sooner had the law been approved by Catalonia's Parliament than it had beenwas challenged by the State before the Constitutional Court, on the grounds that it is equivalent to some of the Municipalities of the municipalities' taxes (the property tax and the economic activities tax). I have had the opportunity of to closely studying this tax closely and believe that it is not similar to those cited taxes, as Catalonia's tax is, mainly, a regulatory tax that, among other objectives, aims to limit the establishment of large commercial areas in the cities, while the 
other two taxes serve completely different objectives. However, the opposite conclusion must be drawn if we take into account the interpretation that theby the Constitutional Court of such limits has given. In my opinion, this interpretation is, in many aspects, wrong and seriously damages the financial autonomy of ACs.

13. The administration of ceded taxes by ACs is a major problem that has not, in my opinion, received enough attention by politicians and scholars. As the excellent study of García Martínez (2000) shows, this administration is, generally speaking, quite inefficient. This is due to several reasons that the author thoroughly explains in this work and which can be summarized into one: the amazing lack of cooperation between the ACs and the State in this task.

14. Law 21/2001, 27 December, por la que se regulan las medidas fiscales y administrativasdel nuevo sistema de financiación de las Comunidades Autónomas de régimen común y Ciudades con Estatuto de autonomía. (hereafter, the LSF)

15. By Section 50 of the Economic Agreement Law (Law 12/2002, 23 May, por la que se aprueba el Concierto Económico con la Comunidad Autónoma del País Vasco).

16. Law 13/2002, 23 May, por la que se aprueba la metodología de señalamiento del cupo del País Vasco para el quinquenio 2002-2006

17. Section 3 of the Economic Agreement Law.

18. Órgano de Coordinación Tributaria de Euskadi (2008)> Informe Anual Integrado de la Hacienda Vasca. (www.euskadi.net, accessed ???).

19. Full details of the Cupo formula can be found in the Fye Yar Cupo Act 2002-2006 (Law 13/2002, 23 May (sections 3 to 8). English versions of ay the legattexts regarding the Basque Country that are quoted in this article can be found at whw.eyskadi.net.

20. Among others, the following are considered charges not assumed by the AC (section 52): (a) The sums allocated in the General State Butget to the 1nter-territorial Compensation Fund referred to in section 158.2 of the Constitution the entribution to this burden shall be made by means of the procedure laid down in the Cupo Act); (b) Transfers or subsidies granted by the State to public entities, profided that he competences exercised thereby have not been assumed by the AC; (c) The rimerest payments and repayments of principle on all State debts as determined in the Cupp baw.

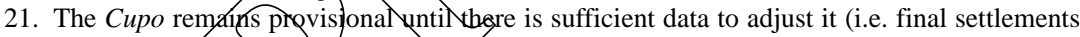
of the taxes etc). Because the calqulation is established for five years, the first (2002 in this case) is used as the 'base year', Which means all the calculations will be adjusted for the subsequent years.

22. Which basically consisted of declaring void a State law that aimed to compensate European non-residents for certain differences in their tax treatment in the foral and common ACs.

\section{REFERENCES}

Agranoff, Robert (1999), 'Intergovernmental Relations and the Management of Asymmetry in Federal Spain', in Robert Agranoff (ed.), Accommodating Diversity: Asymmetry in Federal States. Baden-Baden: Nomos Verlagsgesellschaft, pp.94-117.

Alonso Olea, Eduardo (1995), El Concierto Económico (1878-1937). Orígenes y formación de un derecho histórico. Oñati: Instituto Vasco de Administración Pública.

Beer, Samuel (1997), 'A Political Scientist's View of Fiscal Federalism', in Wallace Oates (ed.), The Political Economy of Fiscal Federalism. Toronto: Lexington Books, pp.21-46.

Bird, Richard (1994), 'A Comparative Perspective on Federal Finance', in K.G. Banting, D.M. Brown and Thomas Courchene (eds.), The Future of Fiscal Federalism. Kingston, Ontario: School of Policy Studies.

Boadway, Robin (2000), 'Recent Developments in the Economics of Federalism', in Harvey Lazar (ed.), Towards a New Mission Statement for Canadian Fiscal Federalism. Kingston, Ontario: Institute of Intergovernmental Relations, Queen's University.

Boadway, Robin (2001), 'Inter-Governmental Fiscal Relations: The Facilitator of Fiscal Decentralization', Constitutional Political Economy, Vol.12, No.2, pp.93-121.

Boadway, Robin and Paul Hobson (1993), Intergovernmental Fiscal Relations in Canada. 
Toronto: Canadian Tax Foundation.

Boadway, Robin and Paul Hobson (1999), Canadian Tax Policy. Toronto: Canadian Tax Foundation.

Castells Oliveres, Antoni (1988), Hacienda autonómica. Una perspectiva de federalismo fiscal. Barcelona: Ariel.

Castells Oliveres, Antoni (2000a), 'The Role of Intergovernmental Finance in Achieving Diversity and Cohesion: The Case of Spain'. Document de treball 2000/2, Institut d'Economia de Barcelona, accessed ??? at www.pcb.ub.es/ieb

Castells Oliveres, Antoni (2000b), 'Autonomía y solidaridad en el sistema de financiación autonómica', Papeles de Economía Española, No.83.

De La Hucha Celador, Fernando (1995), Introducción al régimen jurídico de las Haciendas forales. Madrid: Civitas.

De Otto Y Pardo[??], Ignacio (1995), Derecho constitucional: sistema de fuentes. Barcelona: Ariel.

Fernandez Rodriguez, Tomás Ramón and José Juan Ferreiro Lapatza (1985), 'La financiación de las autonomías', in various authors[??], La España de las Autonomías. Madrid: Ministerio de Administraciones Territoriales.

Ferreiro Lapatza, José Juan (1985), La Hacienda de (2as Comunidades Autónomas en los diecisiete Estatutos de Autonomía. Ed. Generalitat de Całlunya, Barcelona.

García De Enterria, Eduardo and Tomás Ramón Fernandez (1999), Curso de Derecho Administrativo (I). Madrid: Cívitas.

García Martinez, Andrés. (2000), La Gestión de los tributos axtondmżos. Madrid: Cívitas.

García-Milá, Teresa and T.J. McGuire (2003), 'Fis Decentralization in Spain: An Asymmetric Transition to Democracy'. Forthcoming in R. Bid (ed.), Subsidiarity and Solidarity: The Role of Intergovernmental Fiscal Relations in Maintaining an Effective State in Diverse Countries. Washington, DC: World Bank.

García-Monco, Antonio (1996), Autokonxía fixanciera de las Comunidades Autónomas. Valladolid: Lex Nova.

García Morillo, Joaquín, Pablo Perez Tremps and Juan Zornoza Perez (1998), Constitución y financiación autopomicd. Tianciant lo blanch alternativa.

García Ruiz, E. Jos and Giron Regueka (1997), 'La incidencia del modelo de Estado en el sistema de frnanciación aatonómiga' Revista Española de Derecho Constitucional, No.51.

Generallidad De Catalunxal??] (1985), Libro blanco del gobierno de la generalidad de Cataluña sobre la financiación àxonómica. Departamento de Economía y Finanzas.

Heald, David and Neal Geaughrap (1996), 'Financing a Scottish Parliament', in Stephen Tindale (ed.), The State and the Nations. London: Institute for Public Policy Research, pp.167-83.

Heald, David, Neal Geaughan and Colin Robb (1998), 'Financial Arrangements for UK Devolution', Regional and Federal Studies, Vol.8, No.1 (Special Issue: Howard Elcock and Michael Keating (eds.), 'Remaking the Union. Devolution and British Politics in the 1990s'), pp.23-52.

Liquidacion De Presupuestos De Las Comunidades Y Ciudades Autónomas (2003), Dirección General de Fondos Communitarios y Financiación Territorial. Madrid: Ministerio de Hacienda.

López Guerra, Luis (1993), "The Development of the Spanish "State of Autonomies" 19781992', in Jutta Kramer (ed.), Föderalismus zwischen Integration und Sezession. BadenBaden: Nomos Verlagsgesellchaft.

López Guerra, Luis (1996), 'Regions and Nationalities in Spain: The Autonomous Communities', in: Gisela Färber and Murray Forsyth (ed.), The Regions - Factors of Integration or Disintegration in Europe? Baden-Baden: Nomos Verlagsgesellschaft.

López Guerra, Luis (1998), 'The Spanish Constitutional Court and Regional Autonomies in Spain', in ?? D’Atena (ed.), Federalism and Regionalism in Europe. Napoli: Editoriale Scientifica.

McLure, Charles. (2000), 'Tax Assignment and Subnational Fiscal Autonomy', Bulletin (IBFD), Vol.54, No.12.

Medina Guerrero, Manuel (1991), Los regímenes financieros forales en la Constitución de 1978. Oñati: Instituto Vasco de Administración Pública. 
Ministerio de Hacienda (2001), Secretaría de Estado de Presupuestos y Gastos: Informe sobre la financiación de las Comunidades y Ciudades Autónomas. Ejercicio 1998. Madrid.

Monasterio Escudero, Carlos, Joaquim Sole Vilanova, Ramón Falcon Y Tella and Gabriel Casado Ollero (1995), 'Corresponsabilidad fiscal: cuatro opiniones y un criterio común', Perspectivas del Sistema Financiero, No.51.

Monasterio Escudero, Carlos and Javier Suarez Pandiello (1993), Financiación autonómica y corresponsabilidad fiscal en España. Bilbao: Fundación BBV.

Monasterio Escudero, Carlos and Javier Suarez Pandiello (1998), Manual de Hacienda autonómica y local. Barcelona: Ariel.

Moreno, Luis (1999), 'Asymmetry in Spain: Federalism in the Making?', in Robert Agranoff (ed.), Accommodating Diversity: Asymmetry in Federal States. Baden-Baden: Nomos Verlagsgesellschaft, pp.149-68.

Órgano De Coordinación Tributaria De Euskadi (2002), Informe Anual Integrado de la Hacienda Vasca, accessed ??, www.euskadi.net

Ortiz Calle, Enrique (2001), 'Fiscalidad ambiental y límites al poder tributario autonómico (a propósito de la Sentencia 289/2000, de 30 de noviembre, del Impuesto balear sobre Instalaciones que incidan en el Medio Ambiente)' Revista Interdisciplinar de Gestión Ambiental No.3 (March).

Perez Tremps, Pablo (2000), 'La participación de las Conurưdades Autónomas en los asuntos comunitarios europeos', in Enrique Álvarez Conde (ed), Administraciones Públicas y Constitución. Madrid: Instituto Nacional de Adminis Tración Rública (INAP).

Qunitana Ferrer, Enrique (1996), Reforma de la Hacienda dutonophica y libro blanco sobre financiación de las Comunidades Autónomas. Kalencia: Tirant lo blanch.

Ramallo Massanet, Juan (1988), 'El reparto de coppetenclas tributarias entre los distintos ámbitos de gobierno'. Revista Españolgde Dexecho Eindnciero, No.60.

Ramallo Massanet, Juan (1993), 'La asinetria del poder Tributario y del poder de gasto de las Comunidades Autónomas', Revista Espxñold de Derecho Constitucional, No.39.

Ramallo Massanet, Juan (1995), 'Prologd' in K De La Hucha Celador, Introducción al régimen jurídico de las Haciendas forales. Barcelona: Civitas-La Caixa.

Ramallo Massanet, Jyan and Jan Zornoza Perez (1995), 'Sistema y modelos de financiación autonómica', P/erspeczivas del SistenefFinanciero (Fundación FIES, Madrid), No.51.

Ramallo Massanet, Juan and Juan Zornoza Perez (2000), 'El Consejo de Política Fiscal y Financiera y las Condosiones mix en la financiación de las Comunidades Autónomas', Papeles de Econduía Española, No.83.

Rodriguez Bereijo, Álvaxo (1985), 'Una reflexión sobre el sistema general de la financiación de las Comunidades Autononas', Revista Española de Derecho Constitucional, No.15.

Ruiz Almendral, Violeta (2002a), 'Fiscal Federalism in Spain: the Assignment of Taxation Powers to the Autonomous Communities', International Bureau of Fiscal Documentation. European Taxation, Vol.42, No.11 (November).

Ruiz Almendral, Violeta (2002b), 'La regla de la supletoriedad en relación con la atribución de competencias normativas a las Comunidades Autónomas sobre los impuestos cedidos', Crónica Tributaria, No.105.

Ruiz Almendral, Violeta (2003a), Impuestos Cedidos y Corresponsabilidad Fiscal (forthcoming). Valencia: Tirant lo blanch.

Ruiz Almendral, Violeta (2003b), "La fórmula canadiense del "sistema tributario representativo" como una posible forma de profundizar en el sistema de corresponsabilidad fiscal', Revista Valenciana de Economía y Hacienda, No.7.

Ruiz-Huerta, Jesús and J. López Laborda (1997), 'Catorce preguntas sobre el nuevo sistema de financiación autonómica’, in Informe Comunidades Autónomas 1996. Barcelona: Instituto de Derecho Público.

Sole-Vilanova, Joaquim (1990), 'Regional and Local Finance in Spain: Is Fiscal Responsibility the Missing Element?', in R.J. Bennett (ed.), Decentralization, Local Governments and Markets. Oxford: Clarendon Press.

Watts, Ronald (1994), 'The Value of Comparative Perspectives', in Keith Banting, Douglas Brown and Thomas Courchene (eds.), The Future of Fiscal Federalism. Kingston, Ontario: School of Policy Studies. 
Watts, Ronald (1999), 'The Theoretical and Practical Implications of Asymmetrical Federalism', in Robert Agranoff (ed.), Accommodating Diversity: Asymmetry in Federal States. BadenBaden: Nomos Verlagsgesellschaft, pp.24-42.

Wiltshire, Kenneth (1980), 'Working with Intergovernmental Agreements - The Canadian and Australian experience', Canadian Public Administration, Vol.23, No.3.

Zornoza Perez, Juan (1988), 'Tributos propios y recargos de las Comunidades Autónomas'. Madrid: Memoria de la Asociación Española de Derecho Financiero[??]. 1986/87, Vol.II.

Zornoza Perez, Juan (1996), 'Los recursos de las Comunidades Autónomas'. Cuadernos y Debates (Centro de Estudios Constitucionales, Madrid), No.8.

Zornoza Perez, Juan (1997), 'Corresponsabilidad fiscal y financiación de las Comunidades Autónomas: el modelo para el quinquenio 1997-2001', in Jiminez-Blanco and Martinez Simancas (ed.), El Estado de las Autonomías. Madrid: Ceura.

Zubiri, Ignacio (2000a), El sistema de Concierto Económico en el contexto de la Unión Europea. Bilbao: Círculo de Empresarios Vascos.

Zubiri, Ignacio (2000b), 'La capacidad normativa de las comunidades forales. Su extensión al esto de Comunidades Autónomas'. Papeles de Economía, No.83.

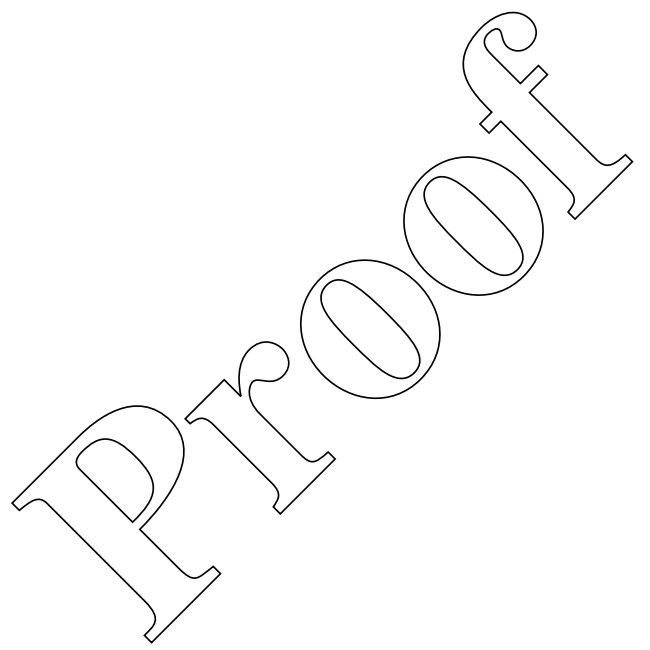

